\title{
Reflections of a Chemist: My Road to Biochemistry and Biotechnology
}

\author{
Peter Biely* \\ Institute of Chemistry, Slovak Academy of Sciences, Bratislava, Slovakia \\ *Corresponding Author: Peter Biely, Institute of Chemistry, Slovak Academy of Sciences, Bratislava, \\ Slovakia
}

\section{INTRODUCTION}

I am aware that my position in science may not entitle me to write this type of a memorabilia article. However, I have decided to do so mainly due to impulse from a number of friends and colleagues, particularly from abroad, who consider my scientific career quite unique particularly because it started in Eastern Europe during time of the divided world, survived turbulent times of cold war and matured after political changes in Czechoslovakia in 1989. Other reason of writing these reflections is the fact that science became the essence of my life. As a graduate in analytical chemistry I was lucky to find myself on the track of interesting biochemistry and biotechnology basic research, a source of my satisfaction and happiness. One of the highlights of my research life was an incredible integration with world science. This offered me the opportunity to visit many countries and interact with many colleagues and scientists from all over the word, who became my friends enriching not just my scientific but also my private life.

\section{EARLY YEARS AND UNIVERSITY STUDIES}

I was born on June $27^{\text {th }} 1941$ in a small Slovak village called Solčany into a family of teachers. I graduated with distinctions from high school in the town Holíc in Western Slovakia in 1958. My parents thought me to be a responsible student and seeded in me a love for nature and music. One of my best high school teachers, Prof. Štefan Paučák tried to attract my interest to chemistry, however, I decided to study geology, which was a specialty of my uncle Anton Biely, a younger brother of my farther. I submitted my application to the Faculty of Natural Sciences of the Comenius University in Bratislava, capitol of Slovakia. Unfortunately in 1958 the University did not open the geology courses and I received an offer to study the combination of chemistry-physics or to wait for a geology opening in the next year. The loss of one year was unacceptable for me and I agreed to start my chemistryphysics studies. After the third year we stood before decision to specialize either in chemistry or physics or take both subjects with a prospect of graduating as a high school teacher. I chose to specialize in analytical chemistry since the Department of this chemistry branch had at that time the best reputation in the Faculty. It offered part time assistant jobs to the best students and was led by one of the foremost Slovak chemists of that time, Prof. Samuel Stankoviansky. One of the selected students was my schoolmate Zuzana Kompišová who later became my wife for my whole life. In 2015 we celebrated the $50^{\text {th }}$ anniversary of our wedding.

In the fifth year of the studies I was lucky to become a diploma student of Prof. Stankoviansky. The project of my MS thesis was an elaboration of a new precise analytical procedure for the determination of fluorine in urine samples of workers from the aluminum producing factory in the town Žiar nad Hronom and in the surrounding plants endangered by factory pollutants. The results of my MS thesis were summarized in my two very first publications and I even had chance to demonstrate our new method in the aluminum factory laboratories. I graduated with distinctions, as we say, with a "red diploma". I should mention here that the Department of Biochemistry, led by Prof. Ladislav Kováč, was in 1961 just starting and became the haven of students active in folklore ensembles. As a student specialized for analytical chemistry I was obliged to take only one semester seminar dedicated to biochemical methods. Without basic knowledge it would be curious to start a carrier in biochemistry. Later I found out that biochemistry is actually an analytical chemistry applied to living matter, to living cells. 


\section{The First Job, Military Service And Final EMPloyer}

Every student graduating from University in 1963 in Czechoslovakia was informed about his/her employer which could be a factory or an academic institution. This was done by a document called "umiestenka", in English translation "job placement". "Umiestnenka" was a result of government regulation of employment, however, it could also be a result of negotiation of the Faculty and the student with the potential employer. That was also my case. I decided to take a job at the Institute of Biology of the Slovak Academy of Sciences in Bratislava where I could pursue my analytical project connected to toxicity of fluorine. One of the reasons to stay in Bratislava was my serious relation with Zuzana Kompišová who lived in Bratislava and joined the Department of Inorganic Chemistry at the Faculty of Chemistry, Slovak Technical University in the city. Nobody could explain to me why my negotiated "umiestenka" to the Institute of Biology was not to the team with whom I had negotiated, but brought me to a dislocated lab of the Institute associated with a starch producing factory in the village Boleráz, about $65 \mathrm{~km}$ distant from the capitol. The head of the lab was Ing. Ján Zelinka, PhD, who later became a Professor of biochemistry. My task in Boleráz was to study the mechanism of surprisingly stimulating effect of cadaverine (a toxic diamine) on production of chlortetracycline by Streptomyces aureofaciens on side products of maize starch isolation. However, after about three months in Boleráz I received a draft notice to start my one year army mandatory service in the Central Army Hospital in Prague at the Army Research Institute. The whole year I spent at the Department of Virology headed by Vice Colonel Dr. Rudolf Benda, where I joined a research project of Major Dr. Jaroslav Činátl on virus multiplication in bottle cultures of cancer cells lines. It was a pleasant army service in a friendly team of medical doctors with numerous friendly ladies, some of them technicians, some of them high rank medical doctors. I wore the uniform only on weekends. As a Slovak I felt comfortable among our Czech brothers though I never switched to easy talking in the close Czech language. I even personally supervised a nice female technician, which was strikingly unusual for a man during mandatory army service. The stay in the army research lab was my first touch with medical biochemistry.

After one year in Prague I returned to Boleráz to renew my work at the Institute of Biology in the group of Ing. Ján Zelinka. He was just back from his visit to the USA from where he brought a glass filter with a clip for filtration of precipitated proteins labelled with radioactive amino acids. At that time it was the method to follow the protein biosynthesis. Boleráz lab was not equipped for chemistry work. Since I was in need of a filter to collect my crystalline chlorotetracycline isolated from fermentation liquids, I asked Ing. Zelinka to let me use his "American"” filter. He replied: "I lend it to you, however, when you break it I'll kill you." Immediately after I entered the lab holding the filter very cautiously, it fell of my hand and broke to pieces on a hard floor. One of the technicians started to crying. Zelinka of course did not kill me, but this incident was the point of quitting my job at the Institute of Biology in Boleráz and moving to Bratislava to join the Institute of Chemistry of the Slovak Academy of Sciences.

\section{InSTITUTE OF CHEMistRy, SLOVAK ACADEMY OF SCIENCES}

To find a doctorate position for me was quite easy because I belonged to University graduates with a good reputation and, on top of that, a brother of Zuzana, my future wife (I married her in June 1965), Dr. Ivan Kompiš was one of influential staff members and in a good standing with the Institute Director Dr. Štefan Bauer. Dr. Bauer was an organic chemist, however, on March $1^{\text {st }}, 1965$ I became his very first biochemistry doctorate student. All this happened during the time when the Institute of Chemistry became definitely specialized in chemistry and biochemistry of carbohydrates and when Dr. Bauer realized the important role of carbohydrates as communication molecules in living cells in addition to their structural and energy-supplying roles. Thus I became the first member of the newly established Dr. Bauer's biochemistry group and my $\mathrm{PhD}$ project was on metabolic transformations of sugar analogues, namely deoxysugars, in the yeast Saccharomyces cerevisiae. The reason was the fact 2-deoxy-D-glucose (2deGlc) was known as glucose antimetabolite exhibiting antitumor activities and that the yeast utilizes anaerobic glycolysis similar to that in tumor cells growing under insufficient supply of oxygen. Development of the blood circulation system stays behind the cell multiplication which leads to cell hypoxia and higher glycolysis. Another idea of Dr. Bauer was to incorporate sugar analogues into polysaccharides or glycoproteins to change their immunochemical properties. It was known that deoxy sugars also play a role of determinant groups of natural antigens. The outcome of my research did not reach the field of immunology, however, during those three years I published with Dr. Bauer five papers on metabolism of $2 \mathrm{deGlc}$ in which we demonstrated that $2 \mathrm{deGlc}$ is not 
only phosphorylated to 6-phosphate but enters sugar nucleotides, with UDP as analogue of glucose and with GDP as analogue of mannose [1,2]. I defended my PhD thesis at the Czechoslovak Academy of Sciences in Prague. It was a typical basic research, a hunt for original, new, unpublished knowledge, without particular requirement for rapid application of results. I successfully preserved this character of my research work throughout my whole career.

Later with Vladimír Farkaš and Zdeno Krátký, new members in the Bauer's biochemistry team, we reported also incorporation of 2 deGlc into saccharose, trehalose, glycogen and even into cell wall polysaccharides [3]. Interference of sugar nucleotide analogues with biosynthesis of cell wall polysaccharides and incorporation of 2deGlc into cell wall mannan was considered to be the main reason for the strong lytic effect of 2deGlc on cells of Saccharomyces cerevisiae. The cell lysis is due to disturbance of the equilibrium between synthetic and lytic processes during the cell wall growth. This view was supported by evidence of secretion of extracellular endo- $\beta-1,3$-glucanase by yeast protoplasts [4]. We observed similar metabolic transformations with 2-deoxy-2-fluoro-D-glucose (2FGlc) not only in yeasts, but also in chicken embryo cells during a visit to our laboratory by Michael F.G. Schmidt from Germany [5]. Accumulation of radioactively labelled 2FGlc in tumor cells in phosphorylated form due to the enhanced level of anaerobic glycolysis became the basis for search for tumors in the body by positron emission tomography [6]. What a pity that this application of sugar analogues could not be developed in our group.

I explored my experience with sugar nucleotides during my one year postdoctoral stay in the group of Prof. Roger W. Jeanloz at the Harvard Medical School in Boston which started in March 1968. This was the time of so called "Prague Spring", a time of political release in Czechoslovakia, so the travel to the West strongly supported by Dr. Bauer could be realized. Dr. Bauer insisted on this type of postdoctoral stay for each of his $\mathrm{PhD}$ students. Prof. Jeanloz was a leading figure in the raising of glycobiology and my chance to join his research helped me a lot to start my biochemistry career. Quite quickly I completed the isolation of identification of a new sugar nucleotide from Micrococcus lysodeicticus, UDP-N-acetylglucosamineuronic acid, a sugar donor of the acidic sugar serving as glycosyl donor in the biosynthesis of the cells walls of this gram positive bacteria [7]. My attempts to isolate the corresponding dehydrogenase failed since the substrate UDP-N-acetylglucosamine was contaminated with ethanol and I was purifying alcohol dehydrogenase instead of the novel enzyme. My wife joined me two weeks before the invasion of Czechoslovakia by the Warsaw Pact armies. Despite having in hands the Harvard appointment for another year, after some hesitation we returned home exactly after one year as was required by our authorities, to take care of our two year old daughter Jana who remained in the care of grandparents. Staying for a longer time would mean termination of my home job contract. Though I felt comfortably in the Harvard lab and sincerely admired America, it was quite a nervous place in 1968-1969 due to the still ongoing Vietnam War, city riots, Martin L. King and Bob Kennedy assassination. We say with a laugh that it was difficult for us to get home through the stream of people moving in the opposite direction.

With new colleagues in Dr. Bauer's team I continued in the line of the previous research with sugar analogues towards understanding the mechanism of yeast cell wall lysis. During this work we had shown that longer exposition of yeast to sugar analogues results in selection of mutants resistant to 2 deGlc or 2 FGlc, but also resistant to catabolic repression [8]. Normal cells sense 2 deGlc or 2de2FGlc metabolites similarly as glucose metabolites, while mutants do not. This approach was explored later in numerous laboratories for isolation of catabolic repression resistant mutants of cellulolytic fungi, producing enzymes in the absence of natural inducers that means constitutively, and also on inexpensive carbon sources, such as molasses. All this happened at the beginning of the 1970s, which we called in our country "normalization time", years in which new "politically more reliable" authorities were installed everywhere and when the contacts with the West became again very restricted. I personally received numerous invitations to join foreign research groups working on effects of sugar analogues or yeast cell wall biosynthesis, which I could no longer accept.

In 1972 I fulfilled all conditions to be awarded at the Charles University in Prague the title RNDr. (Rerum Naturalium Doctoris) and in 1973 I obtained the status of an "Independent Researcher" which was a key requirement to supervise PhD students. I was lucky to start this position officially with Mária Vršanská (Ria), a hard-working and creative Comenius University graduate who, with exception of her foreign stays, accompanied me through my whole professional life (she retired in 2018). She defended the $\mathrm{PhD}$ thesis in 1977 with publications on yeast cell wall lytic system produced by an Arthrobacter [9]. Before her I guided PhD studies of Zdeněk Krátký, whose official supervisor 
was still Dr. Bauer. Zdeněk emigrated to the West at the beginning of 1980s, precisely in 1982, at the time when his leave was considered to be "illegal". We met again in USA during my Canada stay in 1984-1985. His departure was a great loss for our group. As a consequence, Ria Vršanská became the second most senior person in my group and my substitute during all my leaves of absence.

By the end of 1974 Dr. Bauer as an apolitical figure was removed from the position of the Institute Director, and on top of that, the successful, well-cited research of his group on metabolism and effects of sugar analogues on yeast cell wall biogenesis was terminated. The new authorities requested us to turn attention to bioconversion of plant biomass as a renewable source of energy and chemicals. This time collided with the oil crisis that started in 1973.

After initial hesitation about which way to go in this new area we decided to explore the presence of the large yeast collection housed at the Institute. Dr. Bauer with Vlado Farkaš focused more on microbial cellulases. With the help of Dr. Anna Kocková-Kratochvílová, the founder and curator of the collection, we started screening of yeasts for ability to utilize the second most abundant polysaccharide after cellulose in nature, hemicellulose xylan. In contrast to cellulose, xylan was an underutilized plant cell wall component, though its principal building block, the pentose xylose, can be converted to a whole range of chemicals, including non-caloric sweetener xylitol and fuel ethanol. Later I also learned that xylan fragments, xylooligosaccharides, can be used as functional food additives, called prebiotics [10]. We have found that numerous yeast species are capable of growing on plant xylan [11]. The best xylanolytic strains were found in the genus Cryptococcus and Aureobasidium. The xylanolytic system of a selected strain Cryptococcus albidus was studied in detail. With the outstanding help of the technician Maria Cziszárová, who like Ria accompanied me during my whole professional career (she retired in 2016), we revealed the inducible character of the three components of the xylanolytic system differing in cellular location. Extracellular endo- $\beta-1,4-$ xylanase was coinduced with plasma membrane bound xylobiose-permase and intracellular $\beta$ xylosidase [12]. The endoxylanase was the first enzyme purified to homogeneity in our group, a real milestone in our carbohydrate enzymology research [13]. The $C$. albidus xylanase also became the first glycanase of this type with characterized substrate binding site. Its subsite mapping was based on the cleavage pattern of $1-{ }^{3} \mathrm{H}$-reducing end labelled xylooligosaccharides [14], the technique used before for characterization of $\alpha$-amylases with maltooligosaccharides introduced by Japanese scientists [15]. We also mapped substrate binding site of an Aspergillus niger endoxylanase brought to the lab by Ilona V. Gorbacheva, a visitor from Moscow [16]. During this work we introduced plus and minus numbering of subsites, plus subsites right of the catalytic groups towards the reducing end of the substrate, and minus subsites left of the catalytic groups [13]. This system enables easy comparison of substrate binding sites of any glycanases (Fig. 1). This suggestion arrived too early, long before foundation of the CAZy website by Bernard Henrissat and Pedro Coutinho, our "enzyme bible"[17] (Fig. 2). It happened that the same way of subsite numbering was "reinvented" 16 years later by authors (1981 vs 1997) who just replaced our Roman numerals with Arabic ones. [18]. This mode of subsite numbering has become accepted and used worldwide. The reducing-end labelled xylooligosaccharides also enabled to elucidate complex reaction pathways used by retaining endoglycanases, e.g. formation of xylobiose as a single product generated from xylotriose at high substrate concentrations (Fig. 1).

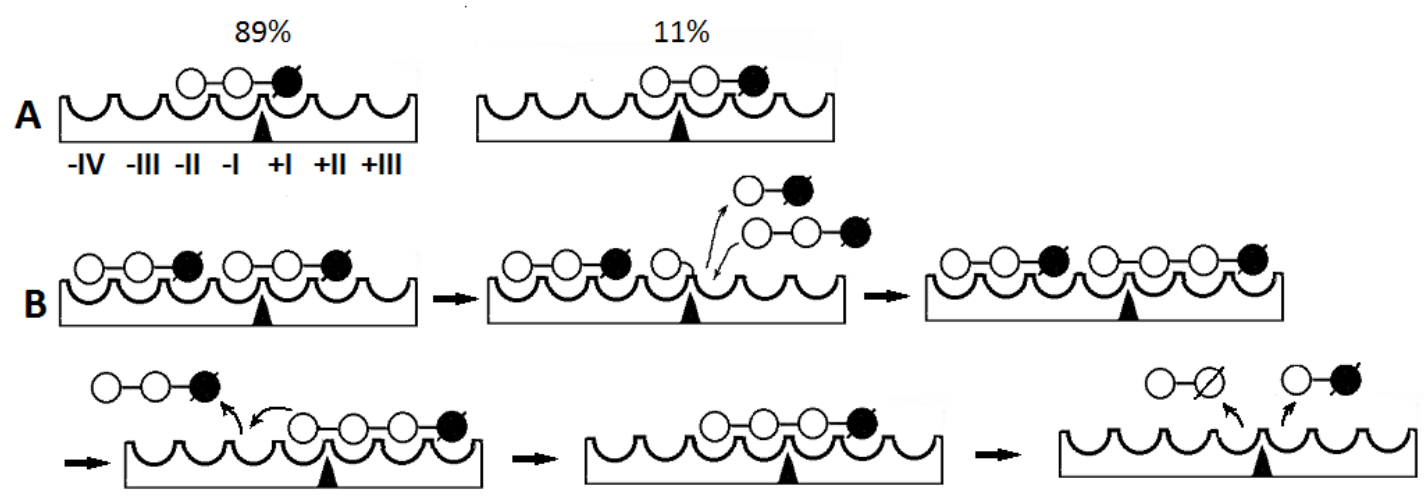

Fig. 1. A. Plus and minus numbering of subsites of glycanases around the catalytic groups introduced in 1981 [14] and cleavage frequency of reducing end labelled xylotriose by Aspergillus niger GH11 xylanase at low substrate concentration $\left(\mathrm{Xyl}_{3} \rightarrow \mathrm{Xyl}_{2}+\mathrm{Xyl}\right) ; \mathrm{B}$, a complex reaction pathway of xylotriose degradation at high substrate concentration leading to xylobiose as the single product $\left(2 \mathrm{Xyl}_{3} \rightarrow 3 \mathrm{Xyl}_{2}\right)$ [16]. 
In the first half of 1980s several skillful and talented young ladies joined our group. Mária Hrmová participated in studies of the induction of xylanases and cellulases in the yeast Trichosporon cutaneum [19] and fungus Trichoderma reesei [20], Eva Petráková contributed to understanding of the role of positional isomers of oligosaccharides in the induction plant cell degrading enzymes. She was the first to examine the inducible effect of positional isomers of 1,4- $\beta$-xylobiose [21]. The work was based on earlier findings that not cellobiose but its positional isomer, sophorose, is the natural inducer of cellulases in T. reesei [22]. C. albidus also remained a model microorganism for my next $\mathrm{PhD}$ student Alena Peciarová-Vancová. She studied in detail the role of two different $\beta$-xylosidases in xylan utilization. In addition to the intracellular enzyme hydrolyzing xylooligosaccharides transported to the cells by the permease, the yeast also produced a strictly cell-wall bound aryl- $\beta$-xylosidase not involved in xylan utilization [23].

In this period we started a collaboration with the most experienced biochemists in the house, Oskar Markovič and with organic chemist Danica Mislovičová on synthesis of specific chromogenic substrates of endoglycanases. The idea was to develop soluble covalently dyed polysaccharides precipitable with ethanol from aqueous media and usable in agar gels for selection of enzyme producers or detection of enzymes on electrophoretic gels [24]. The principle of the assay is simple: the dyed polymer does not diffuse in agar gels, while its short dyed fragments do, which results in decolorization of the colored background at the place of the enzyme action. These substrates and their multiple uses turned out to be one of our most important methodological contributions to this area of research (Fig. 3). Blue xylan dyed with Remazol Brilliant Blue and hydroxyethylcellulose dyed with Ostazine Brilliant Red were two specific xylanase and cellulose substrates produced on a larger scale in the Realization Department of the Institute and commercialized through the Sigma Chemical Company. The two substrates enabled for the first time, not just the detection of specific cellulases and xylanases in gels, but also of non-specific cellulases exhibiting xylanase activity [25,26]. Analogous substrates for endo- $\beta$-1,4-mannanases and endo- $\alpha-1,4$-glucanases ( $\alpha$-amylases) were prepared by attaching the dyes to $\beta$-galactomannan and starch. Important aspect of the covalently dyed polysaccharide is that they enable endoglycanase assays in samples containing high background of reducing sugars or other interfering compounds. The substrates were successfully used for determination of endoglycanase activities in rather dirty soil extract in the thesis of Branislav Šušlík, my $\mathrm{PhD}$ student from the Forest Ecology Institute of the Slovak Academy of Sciences in the city of Zvolen. Currently a larger selection of similar substrates is available from Megazyme Int. (Ireland) directed by a friend of mine, Barry McCleary (Fig. 2), with whom I have been in contact since the 1990 ACS Symposium in Boston.

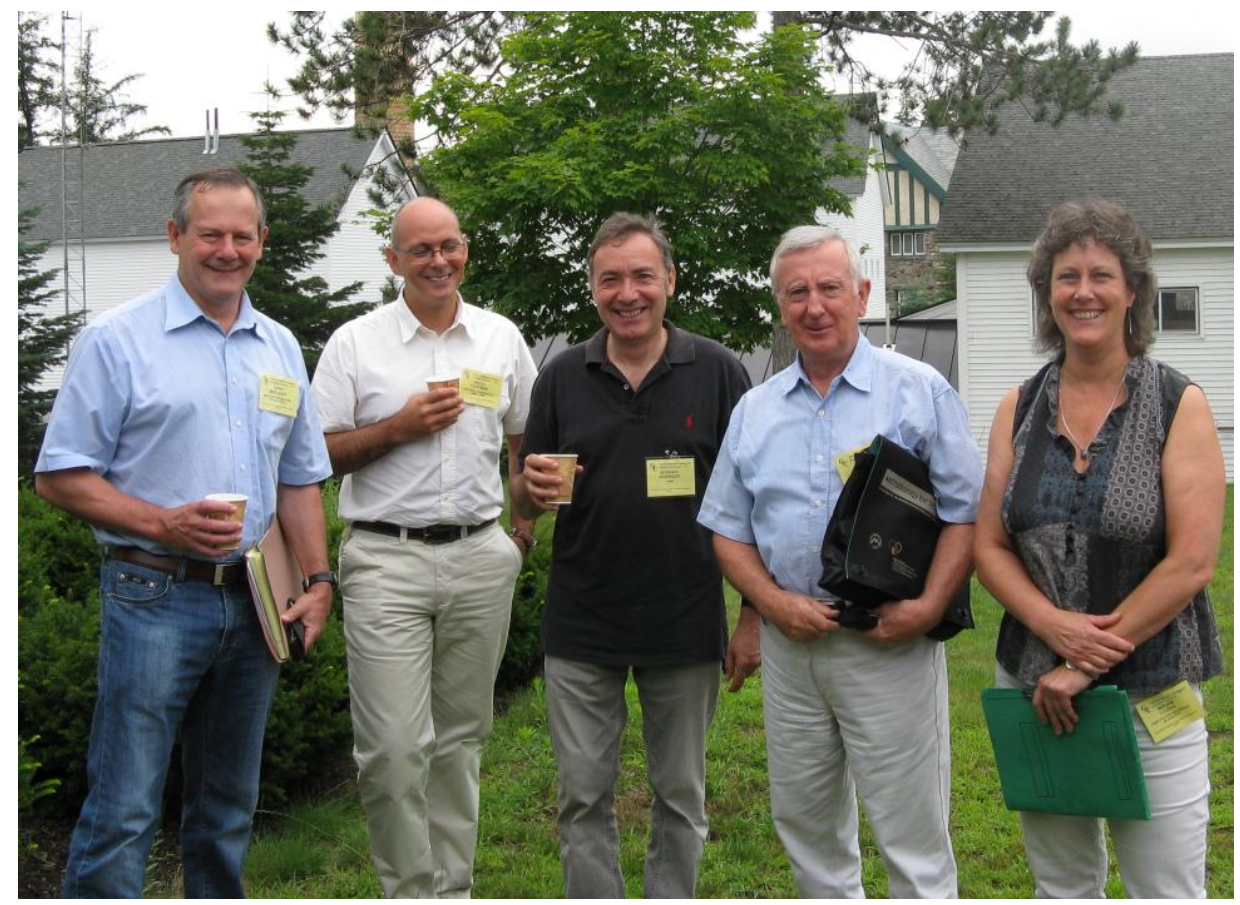

Fig. 2. At the 2009 Gordon Conference on Carbohydrate Active Enzymes (Proctor Academy, Andover, NH, USA). From the left: President of Megazyme Int., Barry McCleary, founders of CAZy Pedro Coutinho and Bernard Henrissat, author and a French marine glycobiologist Mirjam Czjzek. 


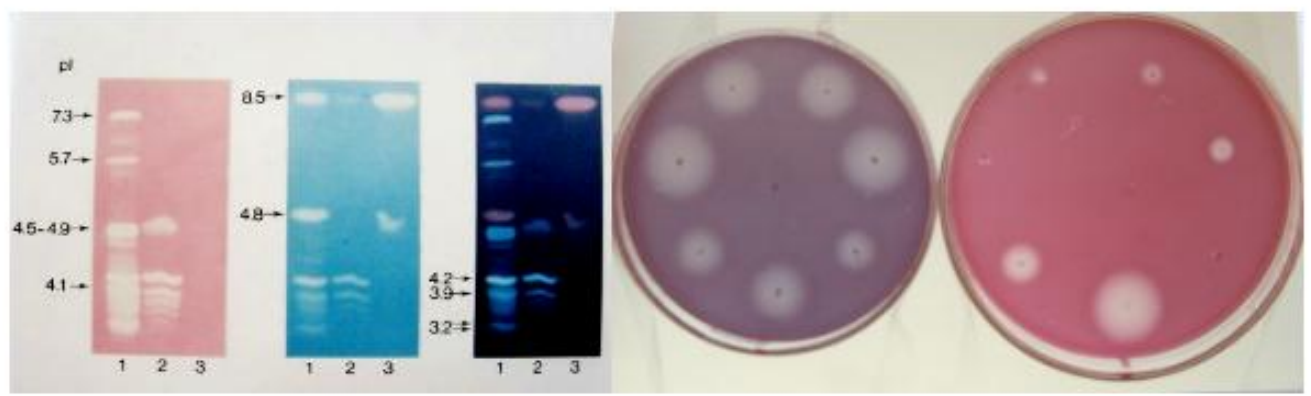

Fig. 3. Ostazin Brilliant Red-hydroxyethylcellulose and Remazol Brilliant Blue-glucuronoxylan used for detection of endo-acting cellulases and xylanases on electrophoretic gels and screening of producers of the two types of glycanases [25].

\section{MiCROBIAL ESTERASES}

The middle of 1980s was marked in the Czechoslovakia with a sign of continual political relaxation. The contacts with the West became easier and easier. As a result of this change, in 1984 I was allowed to accept a one year position as a Visiting Research Officer at the National Research Council of Canada (NRCC) in Ottawa in the group of Henry Schneider, called Pentose Canada Group. Henry's interest was to find yeasts that would be capable to ferment xylose to ethanol. He succeeded to find this ability in Pachysolen tannophillus [27], so he also became deeply interested in enzymatic conversion of plant hemicellulose to this monomer. One of the available sources of xylose was hardwood hemicellulose released from hardwood by steam explosion. Here I learned for the first time that such xylan is partially acetylated because the native glucuronoxylan is partially acetylated. Up to that time I came into touch just with alkali extracted xylan, which is, of course, completely deacetylated. I realized immediately that if this is the case, microorganisms degrading such acetylated polymer in Nature must produce esterases that liberate acetic acid and act together with other glycanases. In Ottawa I set up the simplest experiment in my life which led to discovery of novel enzymes which we named acetylxylan esterases. I incubated solution of hemicellulose obtained from the steam explosion process with native and thermally denatured commercial cellulase preparation. Next morning I measured the changes in $\mathrm{pH}$ of the solution - no change with denatured enzymes and significant acidification with the native cellulase preparation. Eureka! This was the discovery of a new group of enzymes participating in microbial plant cell wall degradation [28]. This led subsequently to discovery of feruloyl esterases and a whole range of other deesterifying enzymes. I quote this experiment in lectures to students as an example demonstrating how simple can be the road to scientific discoveries. In later years polysaccharide deacetylases became one of the primary objects of my research practically till my retirement. I shall not exaggerate if I say that in this research domain our group dominated worldwide $[29,30]$. In view of a biotechnological potential, these enzymes are indispensable only in enzymatic saccharification of plant hemicellulose extracted under non-alkaline conditions. With a Canadian postdoc in the Henry's team, Hung Lee, one of my best friends among overseas scientists, we published the first positive trials to produce ethanol directly from xylan using xylanolytic yeasts with simultaneous capacity to ferment xylose [31].

\section{My Professional Life after Political Changes in 1989}

The degree DrSc is awarded in Slovakia to established and internationally recognized scientists. Unexpected changes in the country in 1989 removed the political barrier to present my "big doctorate" thesis in biochemistry in Spring 1990. I was no longer obliged to fulfil previously required political and ideological criteria. The changes also opened for us the gates to the western world of science which I began using without any hesitation into the present time. My desire to travel and work in USA or Canada during the first years of freedom was strengthened by the fact that our son Peter, studying violin playing at the Bratislava Conservatory, was in 1989 selected by an American conductor Sheldon Morgenstern as a talented young violinist for a Summer Violin School in Greensboro, North Carolina. The contest took place in Warsaw, Poland. During the summer course he arranged his 4 year study at the Yale School of Music in New Haven, Connecticut, starting in September 1990. He graduated in 1994 as a "Musicae Magistri" with an Artist Diploma. My journeys overseas, frequently together with my wife, were opportunities to meet our son far away from his home. They also helped me to build life-long friendship with a number of respected American or 
Canadian scientists outside of Peoria. In addition to the names which have appeared in the above text, I should name: Vernon N. Reihold, Peter J. Reilley, Thomas W. Jeffries, Andre Lachance, Jack Saddler, Rolf Morosoli and Dominic W.S. Wong and others.

In 1991 I joined for half a year Repligen Sandoz Research Corporation in Lexington (Mass., USA) which was directed by Roberta L. Farrell, a former PhD student of the prominent figure in the area of lignin biodegradation, T. K. Kirk at the Forest Research in Madison, Wisconsin. In Repligen I investigated with Diane McCay the potential of endo- $\beta-1,4$-mannanases for bleaching of softwood pulp similarly as Liisa Viikari from VTT in Finland discovered that xylanases could facilitate hardwood pulp bleaching [32]. The results were positive, however, they did not reach a stage for their transfer to industry. We were able at least to publish two introductory articles, one on production and characterization of mannanases, another on their bleaching effect. In the meantime Ria finished the study of the mode of cleavage of reducing end labelled cellooligosaccharides by cellulolytic enzymes which led to the first evidence that the two cellulolytic cellobiohydrolases attack the substrate from opposite sides, one from the reducing end, the other from the non-reducing end [33].

In December 1992 I moved from Lexington to Laval, Canada, to the Institute Armand Frappier, Canada, to start my 6-month stay, my first time as a Visiting Professor. I participated on a project on differentiation of multiple endoxylanases of Streptomyces lividans applying similar methodological approaches as those used in my home lab. Xylanases of family GH10 and GH11 differ in the length of the shortest aldouronic acids generated from glucuronoxylan [34] (Fig. 4). The Canadian colleagues led by Dieter Kluepfel were outstanding molecular biologists and my task was to contribute on the side of chemistry and enzymology. A funny story is linked to my questions on the size of cloned DNA fragments. Some of them were long enough to contain two reading frames and in fact one gene of endoxylanase was accompanied by intact gene a new type of acetylxylan esterase. Both enzymes were co-expressed in the recombinant strain, which meant that Peter Biely cloned an acetylxylan esterase gene without touching the gene [35]. Later Vlado Puchart spent his 2 year postdoctoral stay in this Canadian group. More about his contributions follows.

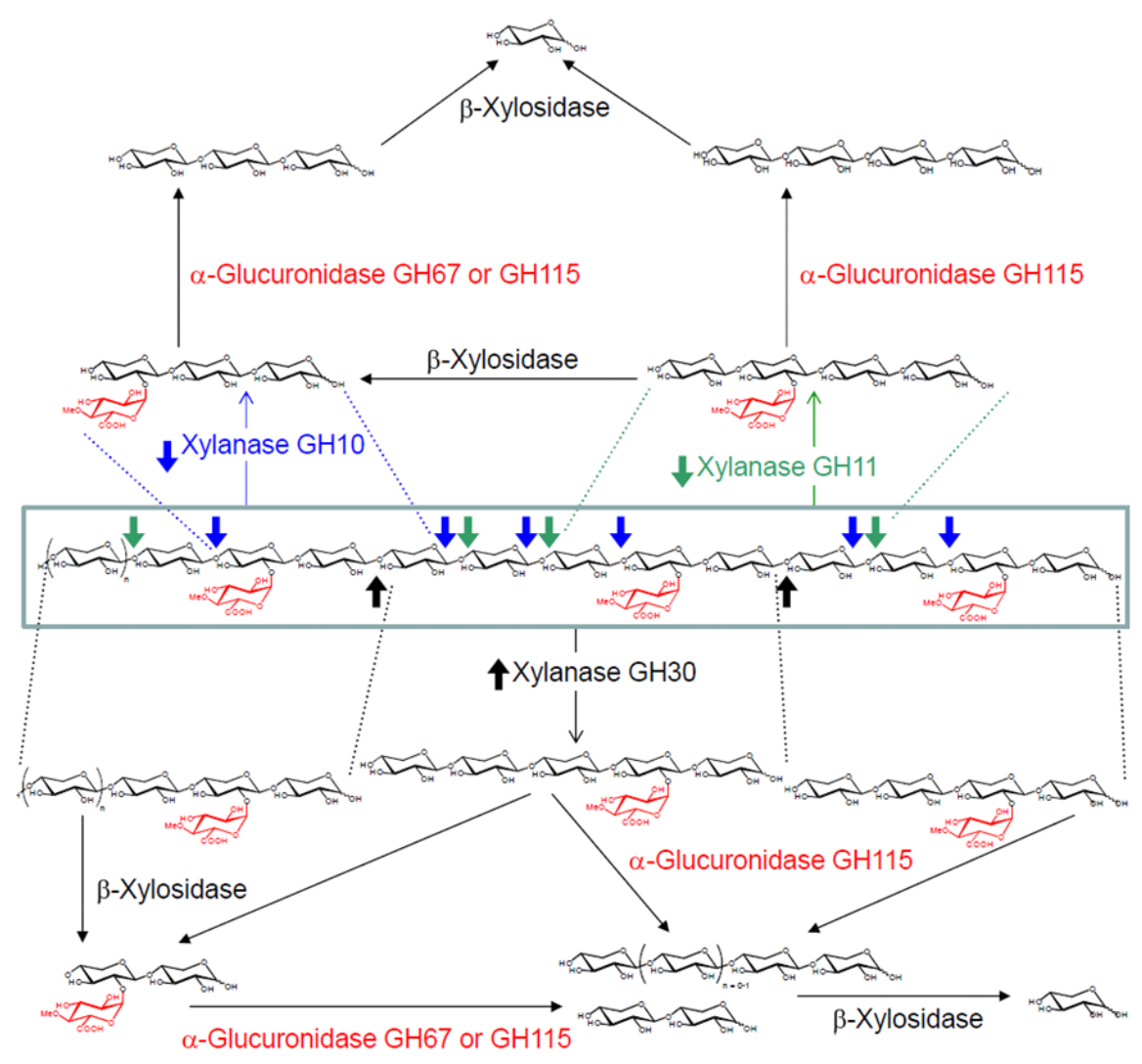

Fig. 4. Enzymatic hydrolysis of alkali extracted hardwood glucuronoxylan (in the frame) by three types of endo- $\beta-1,4$-xylanases (GH10, GH11 and GH30) generating different acidic oligosaccharides and their conversion to xylose by glycosidases. Neutral xylooligosaccharides and 4-O-methyl-D-glucuronic acid released by $\alpha$-glucuronidases are not shown. 
After my return from Canada my interest shifted also to mannanolytic enzymes which were studied by two PhD students, L’ubomír Kremnický and Vladimír Puchart. Lubo completed characterization of a mannanolytic system of the yeast-like Aureobasidium pullulans known to proliferate on wood, contributing to its deterioration [36]. Vlado Puchart started his PhD studies a few years later on fungi when we were invited to participate on Copernicus and INCO Copernicus projects financed by European Commission in the phase of final steps of integration of Slovakia with the European Union. During his work our group registered another milestone. Vlado was my first $\mathrm{PhD}$ student who obtained partial amino acid sequences of enzymes purified from Aspergillus fumigatus which enabled their subsequent CAZy classification exploring rapidly growing bioinformatics [37].

My further journeys to America took place in 1993, 1995, 2000 and 2005, and a 1 ways led me to the laboratories of the Agricultural Research Service of the United States Department of Agriculture in Peoria, Illinois. This is the famous institution where large scale production of penicillin began during the Second World War. I joined the laboratories of Richard V. Greene and Greg L. Côté, task of which was to investigate possibilities of rational utilization of agricultural lignocellulosic byproducts or conversion of saccharose to high value products. During my first Peoria stay I was lucky to discover microbial enzymes synthesizing the first cyclic tetrasaccharide built from glucosyl residues linked by $\alpha-1,3$ and $\alpha-1,6$-glycosidic linkages, called cycloalternan [38,39], a friendly non-reactive molecule suitable for protection of proteins and vaccines (Fig. 5). The discovery became a subject of three international patents with my co-authorship.

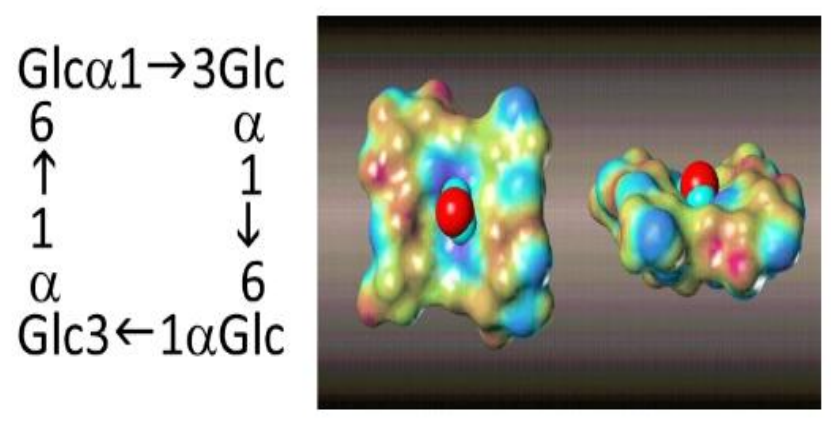

Fig. 5. Cycloalternan - formula and its crystal structure with one water molecule in the middle [38,39].

During the next three Peoria stays I was working on enzymes degrading plant cell walls - that means on projects which overlapped our research of glycanases and carbohydrate esterases in Bratislava. Lubo Kremnický, still serving as my PhD student, joined me in Peoria for a few months in 1995. In 2005 I was in Peoria for three month on a OECD fellowship when he was there on a 2-year postdoctoral stay. During this time we were visited by a new postdoctoral fellow in my group in Bratislava, Mária Mastihubová. Together with her husband we formed in 2005 in the USDA lab a small Slovak colony. Mastihubová is an outstanding organic chemist who stayed with me 5 years and synthesized chemo-enzymatically a series of chromogenic esterase substrates, usually selectively acetylated or feruloylated aryl glycosides. These compounds improved significantly the assays of acetylxylan esterases and feruloyl esterases and contributed to their characterization [40,41]. The latter enzymes liberate phenolic acids esterifying arabinosyl residues in arabinoxylans. During my last visit to Peoria I started a fruitful collaboration with Xin Liang-Li, who cloned several plant cell wall degrading enzymes for us and assisted in introduction of two new families of carbohydrate esterase, CE15 and CE16, into the CAZy webside. CE16 is a non-reducing end deacetylase which catalyzes efficiently transacetylation to carbohydrates in aqueous medium saturated with alkyl acetates, such as vinyl or propyl acetate [42]. I shall dedicate more attention to the CE15 esterases below.

\section{NeW MillenNiUM}

The first decade of the new millennium was marked with wide international collaboration in the frame of so called COST Actions supported by European Commission. We participated in 6 such Actions. The projects were dedicated to variety of aspects of utilization of plant polysaccharides with emphasis on development of enzyme technologies. The outcome of these activities was a large number of joint publications with scientists from Finland, Greece, Belgium, Great Britain and Netherland and Norway. Frequent meetings of the working groups led not only to exchange of experience and techniques, but also to long-lasting friendly relations between participating scientists. The key scientists in this regard were Mahalingeshwara K. Bhat from Great Britain, Marc Claeyssens from 
Belgium, Liisa Viikari, Maija Tenkanen and Johanna Buchert from VTT in Finland, Basil Macris, Paul Christakopoulos and Evangelis Topakas from Greece, Jaap Visser, Henk Schools and Ronald deVries from Netherland and Vladimír Křen from the Czech Republic. With joy and appreciation we frequently recall a non-scientific outcome of one of the COST Actions - a marriage between two young scientists from Western and Eastern Europe.

On the COST projects participated our final three female PhD students. Katarína Kolenová-Šuchová completed a PhD study with Mária Vršanská on diversity of xylanases of the wood-rotting fungus Schizophyllum commune [43]. In the same fungus Silvia Špániková-Mališková discovered a novel carbohydrate esterase that cleaves ester linkages between uronic acid of xylan and lignin alcohols [44]. The enzyme is called glucuronoyl esterase and is classified in CE family 15 . The studies of the new esterase were extended by Miroslava Křupalová-Ďuranová [45]. All three students spent three months in the group of Ronald deVries in Wageningen learning molecular biology and bioinformatics methods. The first glucuronoyl esterase was purified in Bratislava, however, the first recombinant enzyme encoded by gene from Trichoderma reesei was prepared in Peoria by already mentioned XinLiang Li. As the first CE15 member the enzyme was successfully crystallized and its three dimensional structure solved in collaboration with American scientists [46]. It was another important milestone in my research group. Chromogenic substrates for glucuronoyl esterases were introduced during PhD studies of Lucia Fraňová supervised by Vlado Puchart [47]. The biotechnological potential of these relatively new enzymes still remains to be investigated.

The story of glucuronoyl esterase was accompanied with further original contributions to area of endoxylanases and xylan debranching enzymes. In 2007 Mária Vršanská became a first author on the paper describing mode of action of endoxylanases classified in GH30 family [48]. The family harbors enzymes which are specialized for xylan that contains MeGlcA or GlcA side residues (Fig. 4). These relatively new endoxylanases became a subject of our long-term collaboration with the Danish company Novozymes A/S. The enzyme from phytopathogenic bacterium Erwinia chrysanthemi which was prepared in the Novozymes laboratory of Kristian B.R.M. Krogh was successfully crystallized with an oligosaccharide ligand containing MeGlcA. The crystal structure, solved by Lubica Urbániková, showed that the uronic acid recognition by the enzyme is based on bidentate ionic interaction of the uronic acid carboxyl group with an arginine located close to the enzyme active site (Fig. 6) and conserved in the same type of enzymes from other bacterial species [49]. The role of the ionic interaction was confirmed in an enzyme mutant with replaced arginine and with glucuronoxylans in which MeGlcA side residues were either esterified with methanol or reduced to 4$O$-methyl-D-glucose [50]. In later years we found xylanases recognizing uronic acid side chains also in fungi, however, fungal enzymes exhibit lower substrate specificity and higher diversity. Katarína Kolenová-Šuchová recently identified in this family fungal enzyme with strict xylobiohydrolase activity [51]. The enzyme releases xylobiose from the non-reducing end.
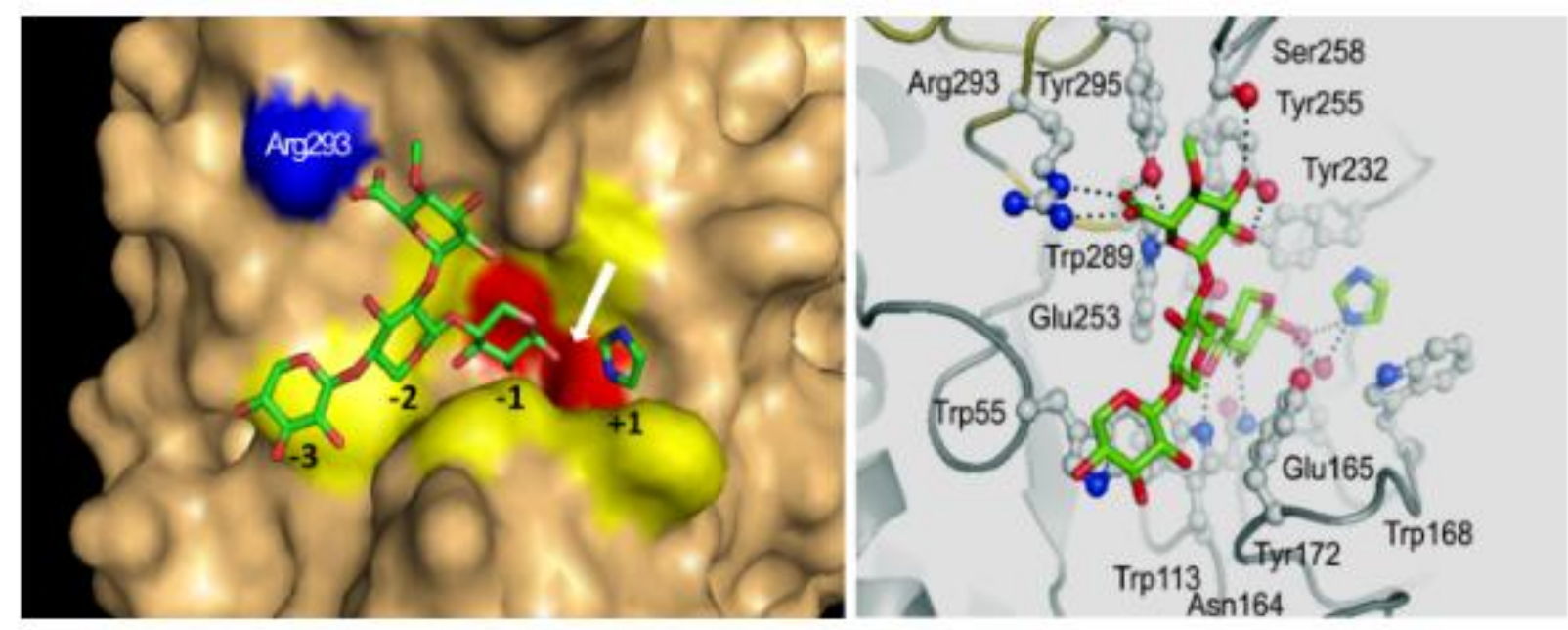

Fig. 6. Aldotetrauronic acid $\mathrm{MeGlcA}^{2} \mathrm{Xyl}_{3}$ crystallized with Erwinia chrysanthemi GH30 endoxylanases specialized for glucuronoxylan [49]. The substrate recognition and the mode of cleavage of the glucuronoxylan main chain is determined by double ionic interaction of the Arg293 with the uronic acid carboxyl group. Xylotriose moiety of the ligand is bound in the three negative subsites. The subsite +1 is occupied with imidazole, a buffer component. The arrow marks the position of catalytic groups. 
Important results were achieved during a 2 year visit of a graduate from Ukraine, Olenka Ryabova. She looked into a curious, not very efficient xylanolytic system of the yeast Pichia stipitis. This species is able to ferment xylose to ethanol and its genome has been sequenced due to initiative of Thomas Jeffries from Madison, Wis. [52]. Tom is one of the overseas scientists with whom I keep contacts since his first visit to Bratislava in 1980th and who pays a great respect to our contribution to current knowledge on microbial degradation of plant cell walls. The yeast produces only a limited set of xylanolytic enzymes, however, one of them, secreted at a high level was a new type of $\alpha$ glucuronidase capable of liberating MeGlcA linked to terminal and internal xylopyranosyl residues of glucuronoxylan. The GH67 $\alpha$-glucuronidase, known for a longer time, recognizes uronic acid on terminal Xyl $p$ residues only. Determination of its partial amino acid sequence by Satoshi Kaneko from Japan and availability of the genome sequence led to introduction of a new glycoside hydrolase family GH115 [53] (Fig. 4). It was the third enzyme family of the CAZy website based on our data. The new type of the debranching enzyme was patented together with the group of Wilhem van Zyl from the Stellenbosch University in South Africa. This was a major outcome of one South AfricanSlovak project of scientific collaboration, a part of my almost 20 year interaction with South African groups which started when Bernard A. Prior invited me to lecture at the MIRCEN UNESCO Biotechnology Course in Bloemfontein in 1998. Later I served several times as a Visiting Professor at the University of Stellenbosch, Durban University of Technology and once at the Western Cape University in Bellville and the Pretoria University. The Professors whom I remain grateful for my unforgettable South African story were Bernard A. Prior, Wilhem H. van Zyl, Donald A. Cowan and Suren Singh, a former PhD student of Bernard Prior.

Collaboration with Yoshihiko Amano and Satoshi Makishima from the Shinshu University of Nagano in Japan and Suren Singh from Durban in 2010 turned our interest to enzymatic xylan conversion to prebiotic oligosaccharides from agricultural byproducts. We reported together on the acetylated nature of xylan and oligosaccharides released from corn cobs in a hydrothermal reactor [54] and looked into possibility to produce prebiotic xylooligosaccharides from variety of agricultural by-products [55].

In addition to the synthesis of a number of chromogenic substrates for CAZy enzymes, frequently used in enzyme-coupled reactions, I should mention our methodological contribution to studies of the positional specificity of acetylxylan esterases. In collaboration with Iveta Uhliariková, an expert for NMR spectroscopy, we were able to assign ${ }^{1} \mathrm{H}-\mathrm{NMR}$ signals of all sorts of acetyl groups in acetylglucuronoxylan and use the changes in their intensity upon incubation with esterases to determine the mode of their action, their positional specificity. In native hardwood glucuronoxylan there are four types of xylose acetylation: single 2- or 3-O-acetylation, double 2,3-di-O-acetylation and 3-O-acetylation of MeGlcA-substituted Xyl $p$ [29]. Most of the acetylxylan esterases, e.g. from families CE1, CE4, CE5, and CE6 ignore the MeGlcA-shielded 3-O-acetyl. Several studies of these enzyme were done together with scientists from the Norwegian University in Aas and University of Marseille. The NMR spectroscopy was recently applied to characterize a new esterase discovered by Razeq et al. [56] attacking the most recalcitrant acetyl groups in the polysaccharide [57] (Fig. 7). The enzyme studied in our group was prepared in Kristian B.R.M. Krogh group in Novozymes in the frame of the Collaborative Agreement, Kristian being the principal investigator on the Danish side [58]. Official collaboration with Novozymes on enzymes degrading plant polysaccharides started in 2009 and the financial support of the projects by the Danish company kept me "scientifically alive" after my seventies.

Here I should mention unforgettable scientific interaction and friendship with three research institutions in South America also working in the area of bioconversion of lignocellulosics. I had privilege to spent a month in the groups of Professors Jaime Eyzaguirre (Andrés Bello National University in Santiago de Chile), Adriane A. F. Milagres (Sao Paulo University, Lorena, Brazil) and Roberto da Silva (Institute of Biotechnology, Sao José do Rio Preto, Brazil). They all pay attention mainly to utilization of side products of sugar cane processing.

\section{IMPACT OF OUR WORK}

The results of my work with colleagues at home and abroad were published in more than 200 reviewed papers and 30 review articles and book chapters. During my career I co-authored 26 Czechoslovak patents and 5 international patents. The papers represented Slovak science with distinction and were well received by the international scientific community. At the beginning of 2020 my WOS citations without self-citations exceeded 8,000 and Hi 45. Google Scholar citations reached 
$11,000+$ and Hi 50. The originality and reputation of our work was the main reason of our participation in 9 projects supported by European Commission (Copernicus, INCO Copernicus, EC FAIR and 6 COST Actions) and 2 projects supported by NATO. My team had also collaborative agreements with companies Novozymes A/S, Denmark (2009-2020), Annikki, Austria (2010-2011), bene-pharmaChem GmbH Co.K.G, Germany (2015-2017) and with the academic institutions Agricultural Research Service of the United States, Department of Agriculture in Peoria (2002-2007) and Norwegian University of Life Sciences in Aas (2012-2013). The above mentioned collaborative projects were financially supported by the foreign partner organizations. The principal aim of all these projects was to improve the efficiency of microbial enzyme systems used for saccharification of plant polysaccharides, plant cell walls. This can be achieved by better knowledge of the processes of microbial decomposition of plant biomass in nature, by introduction of novel enzyme substrates and efficient methods to follow the enzyme action, by discovery of novel enzymes, by selection of better and more stable enzymes, by genetic modification of enzyme producing microorganisms and by better knowledge of the fine structure of plant cell walls. We were quite successful in all these areas. The molecular biology part which was done always in collaboration with more competent laboratories.

My position among biochemists in the country brought me several duties to supervise science in my country. For more than 30 years I have been a member or a chairman of the Commission for Defense of $\mathrm{PhD}$ theses in biochemistry. For 10 years I chaired the Commission for Defense of DrSc theses in biochemistry (we call this degree "big doctorate" or "research professor") and 15 years I served as a member of this commission. I was invited to participate on dozen PhD thesis defenses abroad. I delivered about 60 invited lectures at international scientific meetings and 65 lectures at academic or industrial institutions all around the world.

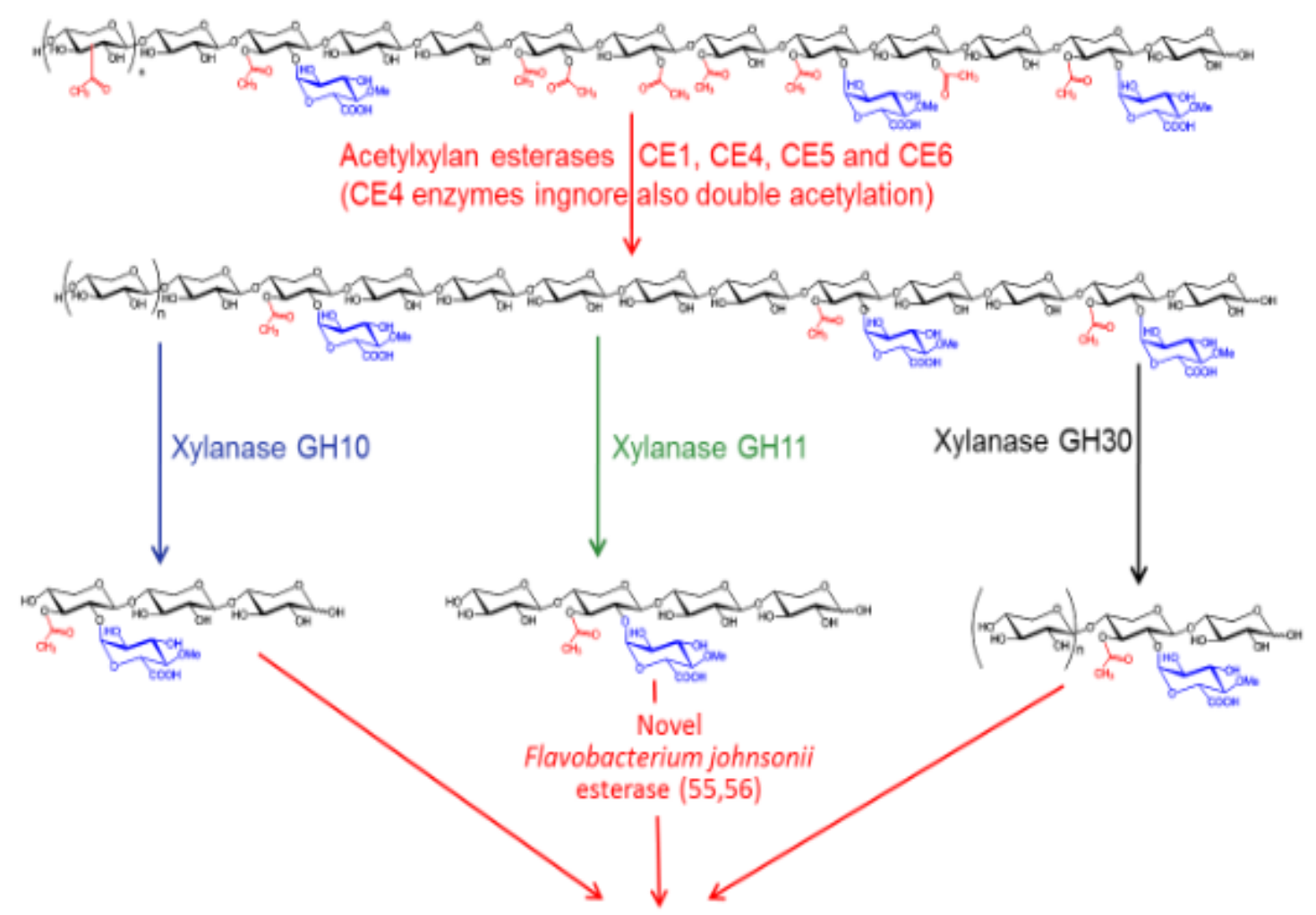

\section{3-0-deacetylated aldouronic acids}

Fig.7. Action of acetylxylan esterases of families CE1, CE5 and CE6 on native hardwood acetylated glucuronoxylan (members of family CE4 do not attack doubly acetylated xylopyranosyl residues) leading to polysaccharide 3-O-acetylated exclusively on MeGlcA-substituted residues [57]. The 3-O-acetyl group which serves as a substrate of a novel $F$. johnsonii esterase does not affect the mode of cleavage of the xylan chain by endoxylanases of three $\mathrm{GH}$ families [58].

\section{ACKNOWLEDGEMENT}

I remain greatly indebted to all who respected and supported our work and contributed to the story presented here. They include not only my Slovak colleagues, but also numerous scientists from 
abroad. Their list of their names would be too long, however, most of them can be found in the references. My special thanks and appreciation should go to my two colleagues Mária Vršanská and Mária Cziszárová for their skill, creativity and enthusiasm and particularly for their patience to stand at my side till their retirement. This conclusion would not be complete without deep gratitude to my family, my wife Zuzana, daughter Jana and son Peter for continual support and understanding.

\section{REFERENCES}

[1] Biely, P., Bauer, Š. (1967): Metabolism of 2-deoxy-D-glucose by baker's yeast. Isolation and identification of phosphorylated esters of 2-deoxy-D-glucose. Collect. Czech. Chem. Commun. 32, 1588-1594.

[2] Biely, P., Bauer, Š. (1968): The formation of guanosine diphosphate-2-deoxy-D-glucose in yeast. Biochim. Biophys. Acta 156, 432-434.

[3] Biely, P., Krátky, Z., Bauer, Š. (1972): Metabolism of 2-deoxy-D-glucose by baker's yeast. IV.Incorporation of 2-deoxy-D-glucose into cell wall mannan. Biochim. Biophys. Acta 255, 631-639.

[4] Biely, P., Farkaš, V., Bauer, Š. (1972): Secretion of $\beta$-D-glucanase by Saccharomyces cerevisiaeprotoplasts. FEBS Lett. 23, 153-156.

[5] Schmidt, M.F.G., Biely, P., Krátky, Z., Schwarz, R. (1978): Metabolism of 2-deoxy-2-fluoro-D-('1H)glucose and 2-deoxy-2-fluoro-D-( ${ }^{1}$ H)mannose in yeast and chick-embryo cells. Eur. J. Biochem. 87, 55-68.

[6] Blodgett, T.M., Meltzer, C.C., Townsend, D.W. (2007) PET/CT: Form and function. Radiology 242, 360380 .

[7] Biely, P., Jeanloz, R. W. (1969): The isolation and structure identification of uridine 5-(2-acetamido-2deoxy- $\alpha$-D-glucopyranosyluronic acid pyrophosphate) from Micrococcus lysodeikticus cells. J. Biol. Chem. 244, 4929-4935.

[8] Biely, P., Kovařík, J., Bauer, Š. (1973): Lysis of Saccharomyces cerevisiae with 2-deoxy-2-fluoro-Dglucose, an inhibitor of the cell wall glucan synthesis. J. Bacteriol. 115, 1108-1120.

[9] Vršanská, M., Krátky, Z., Biely, P. (1977): Enzymes of the yeast lytic system produced by Arthrobacter GJM-1 bacterium and their role in the lysis of cell walls. Z. Allg. Mikrobiol. 17, 465-480.

[10] Nakakuki, T., ed. (1993): In Oligosaccharides. Production, properties and applications. Japanese Technology Reviews Vol. 3, No. 2, Gordon and Breach Science Publishers.

[11] Biely, P., Krátky, Z., Kocková-Kratochvílová, A., Bauer, Š. (1978): Xylan-degrading activity in yeasts: Growth on xylose, xylan and hemicelluloses. Folia Microbiol. (Prague) 23, 366-371.

[12] Krátky, Z., Biely, P. (1980): Inducible $\beta$-xyloside permease as a constituent of the xylan--degrading enzyme system of the yeast Cryptococcus albidus. Eur. J. Biochem. 112, 367-373.

[13] Biely, P., Vršanská, M., Krátky, Z. (1980): Xylan-degrading enzymes of the yeast Cryptococcus albidus. Eur. J. Biochem. 108, 313-321.

[14] Biely, P., Krátky, Z., Vršanská, M. (1981): Substrate binding site of endo-1,4- $\beta$-xylanase of the yeast Cryptococcus albidus. Eur. J. Biochem. 119, 559-564.

15] Suganuma, T., Matsuno, R., Ohnishi, M., Hiromi, K. (1978): A study of the mechanism of action of Takaamylase A on linear oligosaccharides by product analysis and computer simulation. J. Biochem. (Tokyo) 84, 293-316.

[16] Vršanská, M., Gorbacheva, I. V., Krátky, Z., Biely, P. (1982): Reaction pathways of substrate degradation by an acidic endo-1,4- $\beta$-xylanase of Aspergillus niger. Biochim. Biophys. Acta 704, 114-122.

[17] Cantarel, B.L., Coutinho, P.M., Rancurel, C., Bernard, T., Lombard, V., Henrissat, B. (2009): The Carbohydrate-Active EnZymes database (CAZy): an expert resource for Glycogenomics. Nucleic Acids Res 37, D233-238.

[18] Davies, G.J., Wilson, K. S., Henrissat, B. (1997): Nomenclature for sugar-binding subsites in glycosyl hydrolases. Biochem. J. 321, 557-559.

[19] Hrmová, M., Biely, P., Vršanská, M., Petráková, E. (1984): Induction of cellulose- and xylan-degrading enzyme complex in the yeast Trichosporon cutaneum.Arch. Microbiol. 138, 371-376.

[20] Hrmová, M., Biely, P., Vršanská, M. (1986): Specificity of cellulase and xylanase induction of Trichoderma reesei QM 9414. Arch. Microbiol. 144, 307-311.

[21] Biely, P, Petráková, E. (1984): Novel inducers of the xylan-degrading enzymes system of Cryptococcus albidus. J. Bacteriol. 160, 408-412. 
[22] Mandels, M., Parrish, F.T., Reese, E.T. (1962); Sophorose as an inducer of cellulose in Trichodermaviride. J. Bacteriol. 83, 400-408.

[23] Peciarová, A., Biely, P. (1982): $\beta$-Xylosidases and a nonspecific $\beta$-glucosidase wall-bound of the yeast Cryptococcus albidus. Biochim. Biophys. Acta 716, 391-399.

[24] Biely, P., Markovič, O., Mislovičová, D. (1985): Sensitive detection of endo-1,4- $\beta$-glucanases and endo1,4- $\beta$-xylanases in gels. Anal. Biochem. 144, 147-151.

[25] Biely, P. Markovič, O. (1988): Resolution of glycanases of Trichoderma reesei with respect to cellulose and xylan degradation. Biotechnol. Appl. Biochem. 10, 99-106.

[26] Biely, P., Vršanská, M., Claeyssens, M. (1991): The endo-1,4- $\beta$-glucanase I from Trichoderma reesei. Action on $\beta$-1,4-oligomers and polymers derived from D-glucose and D-xylose. Eur. J. Biochem. 200, 157-163.

[27] Schneider, H.,Wang, P. Y.,ChanY. K., Maleszka R. (1981); Conversion of D-xylose into ethanol by the yeast Pachysolen tannophilus. Biotechnology Letters 3, 89-92.

[28] Biely, P., Puls, J., Schneider, H. (1985): Acetylxylan esterases in fungal cellulolytic systems. FEBS Lett. $186,80-84$

[29] Biely, P. (2012): Microbial carbohydrate esterases deacetylating plant polysaccharides. Biotechnol. Adv. $30,1575-1588$.

[30] Biely, P., Singh, S., Puchart, V. (2016): Towards efficient enzymatic breakdown of plant xylans: state of the art. Biotechnol. Adv. 34, 1260-1274.

[31] Lee, H., Biely, P., Latta, R. K., Barbosa, M. F., Schneider, H. (1986): Utilization of xylan by yeasts and its conversion to ethanol by Pichia stipitis strains. Appl. Environ. Microbiol. 52, 320-324.

[32] Viikari, L; Sundquist, J; Kettunen, J. (1991): Xylanase enzymes promote pulp bleaching. Paperija PuuPaper and Timber 73,384.

[33] Vršanská, M., Biely, P. (1992): The cellobiohydrolase I from Trichoderma reesei QM 9414: action on cello-oligosaccharides.Carbohydr. Res. 227, 19-27.

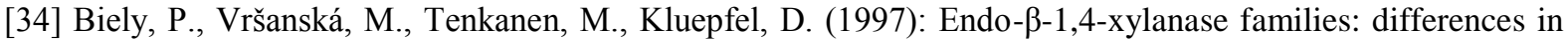
catalytic properties. J. Biotechnol. 57, 151-166.

[35] Shareck, F., Biely, P., Morosoli, R., Kluepfel, D. (1995): Analysis of DNA flanking the xlnB locus of Streptomyces lividans reveals genes encoding acetyl xylanesterase and the RNA component of ribonuclease $\mathrm{P}$. Gene 153, 105-109.

[36] Kremnický, L., Biely, P. (1997): $\beta$-Mannanolytic system of Aureobasidium pullulans. Arch. Microbiol. $167,350-355$.

[37] Puchart, V., Vršanská, M., Svoboda, P., Pohl, J., Ögel, Z.B., Biely, P. (2004): Purification and characterization of two forms of endo- $\beta$-1,4-mannanase from a thermotolerant fungus Aspergillus fumigatus IMI 385708 (formerly Thermomyces lanuginosus IMI 158749). Biochim. Biophys. Acta 1674, 239-250.

[38] Côté, G.L., Biely, P. (1994): Enzymically produced cyclic $\alpha$-1,3-linked and $\alpha-1,6$-linked oligosaccharides of D-glucose. Eur. J. Biochem. 226, 641-648.

[39] Bradbrook, G. M., Gessler, K., Côté, G. L., Momany, F., Biely, P, Bordet, P., Pérez, S., Imberty, A. (2000): $\mathrm{X}$ ray structure determination and modelling of the cyclic tetrasaccharide cyclo[-6)- $\alpha$-D-Glcp-(1,3)- $\alpha$-D-Glcp(1,6)- $\alpha$-D-Glcp-(1,3)- $\alpha-D-G l c p-(1-]$. Carbohydr. Res. 329, 655-665.

[40] Biely, P., Mastihubová, M., van Zyl, W.H., Prior, B.A. (2002): Differentiation of feruloyl esterases on synthetic substrates in $\alpha$-arabinofuranosidase-coupled and ultraviolet-spectrophotometric assay. Anal. Biochem. 311, 68-75.

[41] Biely, P., Mastihubová, M., la Grange, D. C., van Zyl, W.H., Prior, B.A. (2004): Enzyme-coupled assay of acetylxylan esterases on monoacetylated 4-nitrophenyl $\beta$-D-xylopyranosides. Anal. Biochem. 332, 109-115.

[42] Kremnický, L., Biely, P. (2005): Unique mode of acetylation of oligosaccharides in aqueous two-phase system by Trichoderma reesei acetyl esterase. J. Mol. Catalysis B: Enzymatic 37, 72-78.

[43] Kolenová, K., Vršanská, M., Biely, P. (2006): Mode of action of endo- $\beta$-1,4-xylanases of families 10 and 11 on acidic xylooligosaccharides. J. Biotechnol. 121, 338-345.

[44] Špániková, S., Biely, P. (2006): Glucuronoyl esterase - a novel carbohydrate esterase from Schizophyllum commune. FEBS Lett. 580, 4597-4601. 
[45] Ďuranová, M., Špániková, S., Wösten, H.O.B., Biely, P., de Vries, R.P. (2009):Two glucuronoyl esterases of Phanerochaete chrysosporium. Arch. Microbiol. 191:133-140.

[46] Pokkuluri, P.R., Duke, N. E. C., Wood, S. J., Cotta, M. A., Li, X.-L., Biely, P., Schiffer, M. (2011): Structure of the catalytic domain of glucuronoyl esterase, Cip2 from Hypocrea jecorina. Proteins: Structure Function Bioinformatics J. 79, 2888-2892.

[47] Fraňová, L., Puchart, V., Biely, P. (2016): $\beta$-Glucuronidase-coupled assay of glucuronoyl esterase. Anal. Biochem. 510, 114-119.

[48] Vršanská, M., Kolenová, K., Puchart, V., Biely, P. (2007): Mode of action of glycoside hydrolase family 5 glucuronoxylan xylanohydrolase from Erwinia chrysanthemi. FEBS Journal 274, 1666-1677.

[49] Urbániková, L., Vršanská, M., Krogh, K.B.R.M., Hoff, T., Biely, P. (2011): Structural basis for substrate recognition by Erwinia chrysanthemi GH30 glucuronoxylanase. FEBS Journal 278, 2105-2116.

[50] Biely, P., Malovíková, A., Hirsch, J., Krogh, K.B.R.M., Ebringerová, A. (2015): The role of the glucuronoxylan carboxyl groups in the action of endoxylanases of three glycoside hydrolase families: A study with two substrate mutants. Biochim. Biophys. Acta 1850, 2246-2255.

[51] Šuchová, K., Puchart V., Spodsberg N., Krogh K.B.R.M., Biely P. (2020): A novel GH30 xylobiohydrolase from Acremonium alcalophilum releasing xylobiose from the non-reducing end. Enz. Microbiol. Technol. 134, 109484.

[52] Jeffries T.W., Grigoriev, I.V., Grimwood, J., et al. (2007) Genome sequence of the lignocellulosebioconverting and xylose-fermenting yeast Pichia stipitis. Nat. Biotechnol. 25, 319-326.

[53] Ryabova, O., Vršanská, M., Kaneko, S., van Zyl, W.H., Biely, P. (2009): Novel family of hemicellulolytic $\alpha$-glucuronidase. FEBS Letters 583, 1457-1462.

[54] Arai, T., Biely, P., Uhliariková, I., Sato, N., Makishima, S., Mizuno, M., Nozaki, K., Kaneko, S., Amano, Y. (2019): Structural characterization of hemicellulose released from corn cob in continuous flow type hydrothermal reactor. J. Biosc. Bioengin. 127, 222-230.

[55] Arumugam, N., Biely, P., Puchart, V., Gerrano, A.S., DeMukherjee, K., Singh, S., Pillay, S. (2019): Xylan from bambara and cowpea biomass and their structural elucidation. Int. J. Biol. Macromol. 132, 987-993.

[56] Razeq, F. M., Jurak, E., Stogios, P. J., Yan, R., Tenkanen, M., Kabel, M. A., et al. (2018). A novel acetyl esterase enabling complete deacetylation of substituted xylans. Biotechnology for Biofuels, 11 . https://doi.org/10.1186/s13068-018-1074-3 art. 74.

[57] Puchart V., Krogh K.B.R.M., Biely P. (2019): Glucuronoxylan 3-O-acetylated on uronic acid-substituted xylopyranosyl residues and its hydrolysis by GH10, GH11 and GH30 endoxylanases. Carbohydr. Polym. 205, 217-224.

[58] Puchart V., Gjermansen M., Mastihubová M., Krogh K.B.R.M., Biely P. (2020): Positional specificity of Flavobacterium johnsoniae acetylxylan esterase and acetyl group migration on xylan main chain. Carbohydr. Polym 232, 115783.

Citation: Peter Biely. "Reflections of a Chemist: My Road to Biochemistry and Biotechnology" International Journal of Humanities Social Sciences and Education (IJHSSE), vol 8, no. 1, 2021, pp. 67-80. doi: https://doi.org/10.20431/2349-0381.0801009.

Copyright: () 2021 Authors. This is an open-access article distributed under the terms of the Creative Commons Attribution License, which permits unrestricted use, distribution, and reproduction in any medium, provided the original author and source are credited. 